\title{
FRAGMENTATION, FLUIDITY AND PERSONALIZATION: REMARKS ON SHIFTS IN THE PRO-EUROPEAN PARTY SPECTRUM IN THE REPUBLIC OF MOLDOVA AFTER 2014
}

\author{
Andrei Avram \\ MA (Freie Universität Berlin) \\ Program coordinator, Romania Office, Konrad-Adenauer-Stiftung \\ Andrei.avram@kas.de
}

\section{DOI:10.24193/OJMNE.2017.23.03}

\begin{abstract}
The political party system in the Republic of Moldova has been characterized by instability and divisions along geopolitical lines ever since the country gained independence. Institutional volatility continues to affect especially the pro-European party spectrum and hampers efforts to consolidate the Moldovan center-right. The article argues that the recent reconfiguration among pro-Western forces illustrates how the main traits of the Moldovan party system - fragmentation, fluidity and personalization - were exacerbated by the political, economic and social instability that ensued immediately after the parliamentary elections in November 2014. With the next ballot scheduled to take place in late 2018, it will be essential for center-right parties to overcome these structural weaknesses and find a path towards consolidation.
\end{abstract}

Keywords: Party system, democratization, fragmentation, Republic of Moldova.

Multiparty systems in Central and European countries have since their emergence following decades of one-party-rule and Soviet dominance been viewed as having an essential role of both overcoming the legacies of the Communist period as well as in contributing to the sustainable political transformation of the states of the "third wave of democratisation" (Dellenbrant, 1993, p. 148). Yet it remains largely consensus within the literature that political parties in younger democracies, including Eastern Europe, "are less stable" and that they tend to "split, merge and form and dissolve electoral coalitions and alliances" (Ibenskas and Sikk, 2016). These general observations also hold true for the party landscape of the Republic of Moldova, which has in the past been characterized as "one of the most fluid (...) in Eastern Europe" (Nemerenco, 2008, p. 35), encompassing "executive and personalistic" (Nelson et al., 2010, p. 1) political forces. 
Issue no. 23/2017

More specifically however, the party spectrum in the Republic of Moldova has been divided across geopolitical boundaries, with left-wing structures typically opting for rapprochement with the East, and right-wing forces adopting a pro-Western stance (Boţan, 2016). This split - initially between proponents of integration in the Commonwealth of Independent States (CIS), nowadays of the Eurasian Economic Union (EEU), on the one hand, and those advocating closer ties with the European Union (EU) on the other hand - also reflects different views regarding the cornerstones of the Moldovan political system as a whole, with only the latter being (fully) committed to the model of liberal democracy, whereas the former's set of values include statism, authoritarianism and egalitarianism (Protsyk, Bucătaru and Volentir, 2008, p. 91). These inclinations appeal to a significant part of the electorate in the Republic of Moldova, where migration in the past years has depleted the "ranks" of the urban, working-age, better-educated (potential) middle-class, i.e. what could be the core voters of the center-right. It should also be mentioned that this constellation resulted from an initial divide between forces advocating for the re-establishment of the Soviet state and those in favor of (re-)unification with Romania (Pisica, 2013, p. 312), which subsequently complementarily adopted a pro-European discourse as well.

The complexity of the party landscape in the Republic of Moldova is further augmented by the fact that - despite the existence of two antagonistic foreign policy vectors centrist actors also ensued, with even the first Parliament of the newly-sovereign Republic of Moldova roughly equally divided between the right-wing, Romania-leaning Popular Front, the left-wing pro-Soviet Interfront and what would become the centrist Democratic Agrarian Party of Moldova. In more recent times, it was the Democratic Party of Moldova (PDM) to occupy the position of the latter, being nowadays firmly - at a declarative level - engaged in pro-European rhetoric, but having as late as 2010 initially explored the option of becoming part of a pro-Russian coalition (Boţan, 2016). Furthermore, the Party of Communists of the Republic of Moldova, which dominated the political arena between 2001 and 2009, oscillated between staunch support for closer ties with Russia (until 2003), European integration (2003 - 2009), before reverting to its Eastwards-looking stance. Notably though, center-right Moldovan political forces have since independence been more constant in their geopolitical outlook, with the main differentiating element related to the differing position on possible union with Romania, but not on the pursuit of European integration per se.

This paper aims to very briefly shed light upon shifts in the pro-European party spectrum in the Republic of Moldova in recent years, after the parliamentary elections in 
Issue no. $23 / 2017$

2014 which were followed by a reconfiguration of the center-right forces in the country, in the aftermath of what became publicly known as "the theft of the billion" ("furtul miliardului"), when ca. 1 billion US dollars (representing no less than 12 percent of the Moldovan GDP) disappeared from three Moldovan banks and which generated a profound crisis of trust in the pro-European parties in government. Since this article represents work in progress only - given also the recentness of the developments it touches upon - it does not have the intention to exhaustively cover the topic concerned, but rather to offer an impulse for more profound research in this regard. Also, the present paper does not seek to analyze the broader political ramifications of the on-going political crisis in the Republic of Moldova.

The relevance of understanding the evolution of the pro-European parties in the Republic of Moldova is not limited to the scope of political party analysis. In societies engaged in transformation processes, parties "are the vital point of connection between society and government" and since integration - whether in Eastern or Western structures represents, at least to a certain extent, a raison d'être of transformation as such, it is the role of parties to not only "filter demands and organize them into more or less coherent policy" (Dellebrant, 1993, p. 148), but also to convey to - a more or less disoriented population wherein the destination of transformation lies. Moreover, in the case of the Moldovan political system, the role of parties has been more important than in other post-Soviet states, like Russia or the Ukraine (Büscher, 2004, p. 536), especially due to the fact that initially the 1994 Constitution provided for a semi-presidential system (with a stronger role for Parliament compared to other CIS countries), which was replaced in 2000 by a parliamentary system, thus further enhancing the position of political parties (Büscher and Avram, 2012, p. 294). A further contributing factor in this respect is the election of the Moldovan parliament based upon the proportional representation of parties ever since 1994 (Protsyk, Bucătaru and Volentir, 2008, pp. 43-44), which is to be replaced by a mixed system in a controversial move of the current government, voted upon by Parliament in July 2017 (Sieg, 2017). The proportional system adopted in 1994 "equipped party leaders with the ability to control the majority" (Webster, 2008, p. 232).

Nevertheless, while the systemic prerequisites for a functioning multiparty system have been in place for over two decades, the Moldovan party landscape has not yet reached institutional maturity. The proportional voting system strengthened the role of the party chairmen, but the fact that subsequently new forces emerged centered upon the figure of the founding leader hindered the institutional consolidation of the parties themselves (Bucătaru, 
Issue no. 23/2017

2013, p. 57). Furthermore, this trait of the Moldovan system entails the risk of the party disappearing or losing political relevance, once the founder leaves the political field - a risk further exacerbated by Moldovan parties' high reliance on the personal charisma of the leader (Pisica, 2013, p. 314) .

A further problematic issue is related to the fact that, until 2016, political parties in the Republic of Moldova received no subsidies from the state budget and - given the dire social and economic situation - could also not raise significant funding through membership fees, thus having to rely on donations from private persons or entities. In fact, a recent study pointed out that in 2014, the two main parties in the coalition government, the PDM and the center-right Liberal Democrat Party of Moldova (PLDM), obtained 100 (!) and 60 percent respectively of their funding from individuals, whereas their former (and subsequent) coalition partner, the Liberal Party (PL), also relied entirely (!) on contributions of private persons (Asociaţia Promo-Lex, 2016, p. 23). These structural deficiencies were to lie at the heart of the reconfiguration of the center-right spectrum of the Moldovan party landscape.

In geopolitical terms, the parliamentary election on the $30^{\text {th }}$ of November 2014 produced a majority for the pro-European vector, with the center-right PLDM obtaining 20.16 percent of the votes (23 seats in Parliament), the pan-Romanian PL 9.67 percent (13 seats) and the centrist PDM 15.80 percent (19 seats), totaling 55 seats out of 101 . The highest number of seats (25) was won by the explicitly pro-Russian Party of Socialists (PSRM), led by Igor Dodon, who had defected from the PCRM in 2011, and was shortly thereafter elected PSRM chairman.

However, after the election the afore-mentioned banking scandal was revealed to the public, leading to "a profound political, economic and financial crisis, against the backdrop of an ample protest movement" (Boţan, 2016). Despite long-running coalition talks, by February 2015 only a minority government composed of PLDM and PDM ministers, with parliamentary support of the Communists, could be formed - and only after the initial candidate for the post of premier, the incumbent Iurie Leancă (PLDM), had failed to obtain a vote of confidence, having to be replaced by Chiril Gaburici (backed by the PLDM).

Leancă subsequently left the PLDM and founded the European People's Party of Moldova (PPEM) in a first step of the reconfiguration and renewal of the Moldovan centerright. As part of an electoral platform comprising mostly dissidents from the PLDM, the PPEM took part in local elections on June 14, 2015, obtaining about 7.6 percent of the vote, whereas the PLDM reached a nationwide score of 18.3 percent and the PL 12.6 percent 
(Boţan, 2015). Notably however, in the capital Chișinău - where voting behavior in local elections is more party-oriented than in rural areas - the PPEM became the second-strongest party (after PSRM), with a score of 11.58 percent of the votes for the Municipal Council, whereas the PLDM "had to swallow (...) a bitter pill" in seeing its score fall from over 14 percent (in 2011) to only 3.52 percent (Irmer, 2015, p. 3). Thus, Leancă's move to create his own political movement generated a new element of fragmentation of the center-right Moldovan party landscape, which initially affected only the PLDM (Boţan, 2015).

Not even after the local elections did the crisis in the Republic of Moldova show any signs of abating. Two days before the vote, Gaburici had announced his resignation following a scandal related to his school diploma, and it was only on the $30^{\text {th }}$ of July 2015 that a new government could be formed, led by Valeriu Strelet (PLDM), with the PL and PDM as coalition partners. This cabinet was also destined to be short-lived, with one of the most significant "political earthquakes" in Moldovan politics waiting to take place: on the $15^{\text {th }}$ of October 2015, upon a request by the Prosecutor General of the Republic of Moldova, Parliament voted to strip the founding leader of the PLDM, Vlad Filat, of his parliamentary immunity - a decision which was supported by all parties (PSRM, PCRM, PL, PDM), except for Filat's own party. A few hours later, Filat, who had also served as Prime Minister between 2009 and 2013, was arrested, being accused of corruption offences and of involvement in the "theft of the billion".

With Vlad Filat removed from political life - he was sentenced to nine years in prison only a few months later - the PLDM was plunged in a profound, existential crisis, further deepened by a vote of no-confidence initiated by the Socialists and Communists and supported by the PDM, resulting in the ouster of the Strelet government. In terms of public trust, by November of the same year it had fallen from 15.7 percent in April to 5 percent and in terms of voter intention from 7.1 percent to only 2 percent. These figures at least partly tally with Filat's demise as a public figure, with his trust ratings dropping from 11.9 (April 2015) (Institutul de Politici Publice, 2015a, p. 41) to 3 percent (November 2015) (Institutul de Politici Publice, 2015b, p. 38). Subsequently, the PLDM lost a number of MPs, who left the parliamentary group and a number of which supported a newly-formed ad-hoc coalition of the PDM, PL, and deputies who had resigned from the PCRM, leading to the formation of a new coalition government under Prime Minister Pavel Filip (PDM) in January 2016. The magnitude of the losses incurred by the PLDM in terms of political influence and voting 
Issue no. 23/2017

intention is huge: today it only has five MPs, with only 0.8 percent of Moldovans signaling their wish to vote for the Liberal Democrats in the upcoming parliamentary election.

It would certainly be a methodological error to mono-causally link Filat's fate to the decline of the party he had founded in 2007. Many observers note that he had long been engaged in a feud with the main backer and present-day Chairman of the PDM, Vladimir Plahotniuc, who is widely considered to be the most powerful political and business figure in the Republic of Moldova, and that at least some of the defections from the PLDM resulted from various forms of pressure exerted by Plahotniuc. ${ }^{9}$ But despite the issues regarding pluralism and the rule of law in the Republic of Moldova, it is also clear that the PLDM lacked the institutional resources required to recover from the disappearance of its leader from the political stage.

Notably, the PLDM had in the past also profited from the positive image of Iurie Leancă, whose position as Prime Minister (March 2013 - February 2015) had contributed to his notoriety and who had been more popular than Filat for some time. In November 2014, Leancă's trust rating was 42 percent, whereas Filat stood at only 26 percent (Institutul de Politici Publice, 2014, p. 44). By leaving the PLDM, Leancă initially avoided incurring the same high political costs in terms of image, although certain segments of the media had associated him with the banking scandal as well, especially as "the theft of the billion" had taken place under his tenure as premier. Leancă scored a 37 percent positive trust rating in April 2015 - more than any other Moldovan politician - which declined to a still-positive 30 percent by November 2015. In this context, he could successfully transfer his image upon the PPEM, which was registered in August 2015, and achieved a trust rating of 28 percent in November 2015, with a voter intention of 7 percent (Institutul de Politici Publice, 2015b, pp. $40,42)$.

The public success of the PPEM was limited, however, confirming the fluidity of the Moldovan party spectrum, especially on the center-right. After its initial success as "a proEuropean alternative to the compromised political parties", experts warned that an eventual PPEM rapprochement towards the ruling coalition risked bringing about its downfall (e.g. Boţan, 2015). Precisely this was to happen, with Leancă's party signing a partnership agreement with the governmental coalition in July 2016. By October 2016, the voter intention rate of the PPEM had plummeted to 1.7 percent, with public trust at just 11.6 percent

\footnotetext{
${ }^{9}$ Private ("Chatham House rules") discussions the author attended.
} 
(Institutul de Politici Publice, 2016b, pp. 57, 60). At the presidential election on October 30, 2016, Leancă obtained 3.11 percent of votes. By the time of the presidential vote, however, other center-right actors had already been dominating the pro-European Moldovan party spectrum.

The "theft of the billion" also represented a catalyst for some of the most significant street protests in the history of the country. On February 24, 2015, a civic movement called Platform Dignity and Truth was constituted, with several public intellectuals and experts at the forefront thereof, which later was at the forefront of demonstrations organised against the ruling coalition. During the "autumn of protests" (Irmer and Avram, 2015b), tens of thousands of people were mobilized for mass protests in September, and the main square in Chişinău - in front of the seat of the government - was occupied by tents set up by supporters of the Platform. On the $13^{\text {th }}$ of December 2015, part of the leaders of the civic platform created the Party Platform Dignity and Truth (PPDA), with lawyer Andrei Năstase elected chairman at the first congress of the new political force.

Năstase had already established himself as one of the most vocal critics of the government and of Vladimir Plahotniuc. Although expressing its support for the European path of the Republic of Moldova, the PPDA also became an anti-establishment party, with its leader "polarizing [public opinion, A.A.] very well" (Goşu, 2016). This charismatic approach bore well with the Moldovan public. In November 2015, Năstase reached a positive public trust rating of 29 percent (Institutul de Politici Publice, 2015b, p. 38) - quite a significant result, given the fact that he was not even known to 22 percent of those polled. The Platform - at that moment not officially registered as a party - obtained a score of 32 percent positive trust (Institutul de Politici Publice, 2015b, p. 40), already surpassing Leancă's PPEM. With the protest movement slightly losing momentum in the following spring, not least because one of the key demands thereof - direct elections for the president of the Republic of Moldova - had been met by a (controversial) decision of the Consitutional Court, Năstase's popularity also started to decrease. In April 2016, his positive rating stood at 22.2 percent, with the PPDA at 21.8 percent and a voter intention of 9 percent (Institutul de Politici Publice, 2016a, pp. 37, 44, 47).

Not only protest fatigue was the cause for Năstase and the PPDA's slight decline in rates. On the $23^{\text {rd }}$ of December 2016, Maia Sandu - who had served as Minister of Education under Vlad Filat with support from the PLDM, but had not been a party member - announced her intention to create a new political party, which held its founding congress on May 15, 
Issue no. 23/2017

2016. The statute of the new, center-right Party Action and Solidarity (PAS) mentioned its commitment to European integration (Partidul Acţiune şi Solidaritate, 2016, p. 4). Sandu already had a reputation as an uncompromising reform-oriented figure, but had not been actively involved in party politics before. In the summer of 2015 , she had been nominated by the PLDM for the post of Prime Minister, but was rejected by the PDM and PL, after she had put forward a number of conditions enabling her to be independent in her decisions, such as a right to reject minister proposals from the coalition partners and a public commitment of coalition party leaders to necessary reforms (Irmer and Avram, 2015a). This attitude was well received by the Moldovan public opinion and in November 2015 Maia Sandu was credited with a 39 percent positive trust rating (Institutul de Politici Publice, 2015b, p. 38). By April 2016, this figure had decreased to 31 percent - but this still represented the highest score among all leading Moldovan politicians. At the same time, PAS had a positive trust rating of 26.4 percent and 11.1 percent voter intent (Institutul de Politici Publice, 2016a, pp. 37, 44, 47).

A special note should also be made regarding the Liberal Party (PL), which had been able to slightly enhance its electoral score at the local elections in summer 2015 (from 9.67 to 12.62 percent), thus initially avoiding the decline of the PLDM, not least thanks to the "[geo]political" vote for the mayor of Chişinău, where the incumbent Dorin Chirtoacă (and nephew of PL chairman Mihai Ghimpu) had managed to maintain his position, thanks to the polarization of the electorate in the capital between him and the PSRM pro-Russian candidate Zinaida Greceanîi (Boţan, 2015). Chirtoacă had always been more popular than his uncle and the PL had been dependent on his image as well as on Ghimpu's and in the context of the PL's tactical refusal to initially be part of the governmental coalition in the first half of 2015, the trust ratings of Chirtoacă, Ghimpu and the PL did not suffer from the image blows incurred by the PLDM (and the centrist PDM). In April 2015 Chirtoacă stood at a national positive trust rating of 33.8 percent (second only to Iurie Leancă), Ghimpu at 21.2 percent and the PL at 21.9 percent (Institutul de Politici Publice, 2015a, pp. 41-43). However, the subsequent "political earthquake" also left its mark on the PL. In November 2015 Ghimpu's rating was down to 13 percent, and the PL had declined to 14 percent positive trust, with only 5 percent voter intent (Institutul de Politici Publice, 2015b, pp. 38, 40, 42) - lower than the electoral threshold of 6 percent. Significantly, Chirtoacă still had a trust rating of 30 percent, but unlike at the local elections where he had a prominent role to play, a positive image transfer between him and the party led by his uncle could not take place on the level of 
Issue no. $23 / 2017$

national politics in the context of the reconfiguration of the center-right and the emergence of new actors. The downward spiral of the PL continued into the spring of 2016 - after the PL had joined the new government under premier Pavel Filip. In April 2016, Ghimpu was trusted by only 5.4 percent of the Moldovan public, with the PL at 6.2 percent and a voter intent of only 1.7 percent (Institutul de Politici Publice, 2016a, pp. 37, 44, 47). Chirtoacă, also in decline at 17.4 percent, was still much better placed than both Ghimpu and the PL.

The decision of the Constitutional Court of the Republic of Moldova in March 2016 to reinstate the direct election of the President had thus occurred at a moment when the center-right spectrum of the Moldovan had suffered its most significant wave of fragmentation for several years. The established center-right parties PLDM and PL were in decline, the PPEM had already reached its inflection point and PAS and PPDA had established themselves as relevant pro-European political forces. Given the already personalized nature of the Moldovan party landscape, it appears natural that a direct presidential vote would exacerbate this trait, as presidentialism encourages individual responsibility, since "presidential executive authority resides with an individual who is elected to the position for a fixed period of time" (Kesteloot, De Vries and and De Landtsheer, 2008, pp. 78-79).

In an (ultimately unsuccessful) effort to prevent an electoral win by Igor Dodon, three center-right parties - PLDM, PAS and PPDA - committed to field a common candidate in a move supported by the European People's Party, of which the PLDM is an observermember. ${ }^{10}$ From the very outset, the PLDM decided not to nominate any potential candidate, whereas both PAS and PPDA proposed their respective leaders, Maia Sandu and Andrei Năstase, who both initially entered the presidential race. Despite tensions between the two, Năstase agreed to withdraw from the campaign (and actively supported Maia Sandu) after a poll commissioned by the Konrad-Adenauer-Stiftung revealed that voter intent was higher for Sandu (14.3 percent) than Năstase (13 percent).${ }^{11}$ Moreover, the study had shown that in case of Sandu's withdrawal, only 21.9 percent would vote for Năstase, whereas if the latter would pull out, Maia Sandu could garner 26.54 percent - and thus be better placed in the run-off vote against Dodon, whose entry into the second round had been certain from the very outset. Maia Sandu's first-round result of 38.71 percent was also facilitated by the withdrawal of

\footnotetext{
10 The EPP also (unsuccessfully) appealed to Iurie Leancă to support Maia Sandu as well. For the full press release, see: http://www.epp.eu/press-releases/epp-fully-endorses-maia-sandu-as-the-only-candidate-of-the-centre-right-in-moldovas-presidentialelections/ [Accessed 09/09/17].

${ }^{11}$ The full (unpublished) results are in possession of the author.
} 
Issue no. $23 / 2017$

PDM candidate Marian Lupu, and although she lost the run-off, her score of 47.89 percent was higher than most observers had anticipated. Notably, the other two relevant center-right candidates, Iurie Leancă and Mihai Ghimpu, scored very poorly at 3.11 and 1.80 percent respectively.

While Maia Sandu and Andrei Năstase had been running "neck and neck" in the months before the presidential vote, the fact that ultimately the pro-European party spectrum rallied around the former (Leancă also explicitly endorsed her in the second round) created a new layer of personalization, centered around her. This also impacted upon the ratings of her party - but especially on those of potential competitors in the center-right segment of the political landscape. In April 2017, PAS had a positive trust rating of 38 percent, whereas the PPDA only scored 25 percent. These figures largely correspond to the personal ratings of the two party leaders, with Sandu at 38 percent and Năstase at 28. More significantly though is that when it comes to voter intent, PAS now stands at 24.8 percent and the PPDA at only 4.6 percent (Institutul de Politici Publice, 2017, pp. 47, 50, 55). Thus, it appears that Sandu's electoral performance has convinced voters that her party may be a more reliable (or "safer") option - having seen how the PAS chairwoman can handle an electoral campaign - even if they may also trust the other major center-right political force.

In what would seem to be a negative effect of personalization, both the PPEM and the PL now have historically low polling ratings, with voter intent standing at 1.3 and 0.8 percent respectively. The dismal scores of their leaders in the presidential election will have certainly played a role. Even the positive trust ratings of the two parties are quite low, at 12 and 7 percent. Significantly, the PLDM's open support for Maia Sandu during the electoral campaign - which also meant that there was no active promotion of the image of the party's current leader, Viorel Cibotaru - has pushed its ratings even lower. Positive trust lay at 6 percent in April of this year, whereas voter intent was almost irrelevant at 0.2 percent.

The present paper has shown that the Moldovan pro-European, center-right party spectrum has retained three characteristic traits - fragmentation, fluidity and personalization - with the most recent reconfiguration wave proving that the structural weaknesses of the party system have not fundamentally changed since independence. The established parties PLDM and PL declined alongside their founding leaders, whereas the newly-formed PPEM initially benefitted from the positive image of its chairman, before he also lost the faith of Moldovan voters - along with his still-young political force. Andrei Năstase and Maia Sandu could successfully transfer their positive public images onto their parties, with Sandu later 
Issue no. $23 / 2017$

benefitting from the attention she received during the presidential vote, at least partly at the expense of Năstase's PPDA. It remains to be seen whether this initial cannibalization translates into a longer-term trend.

Moreover, it should be mentioned that while the left was also shaken by the demise of the PCRM - the electorate of which was largely taken over by the Socialists - it is the proWestern spectrum of the Moldovan party landscape that is still in desperate need of consolidation. After Igor Dodon's election as president, the Socialists dominance in the proRussian spectrum has become uncontested, with their voter intent standing at 33.6 percent. While the electoral chances of a common electoral block comprising at least the three parties which supported the idea of a single pro-European candidate in the presidential vote would need to be tested in an opinion poll, the chances of the center-right parties running separately would almost certainly be lower. Should this step not be taken, there appears to be no guarantee that after 2018 a new wave of reconfiguration of the center-right does not yet again shake up Moldovan politics.

\section{References}

- ASOCIAȚIA PROMO-LEX (2016) Strategii, practici şi instrumente de finanţare a partidelor politice în Republica Moldova. Chişinău: Asociaţia Promo-Lex. 30 ${ }^{\text {th }}$ March. Available from: https://promolex.md/old/upload/publications/ro/doc_1459254428.pdf [Accessed 08/09/17].

- BOŢAN, I. (2015) Integrarea europeană - ultimul refugiu al ticăloşilor? [Weblog] Analize şi comentarii politice. $1^{\text {st }}$ July. Available from: http://www.edemocracy.md/monitoring/politics/comments/integrarea-europeana-refugiu-ticalosilor/ [Accessed 07/09/17].

- BOŢAN, I. (2016) Partidele şi pendularea geopolitică [Weblog] Analize şi comentarii politice. $\quad 1^{\text {th }} \quad$ November. Available from: http://www.edemocracy.md/monitoring/politics/comments/partide-pendularea-geopolitica/ [Accessed 07/09/17].

- BUCĂTARU, I. (2013) Instituţionalizarea partidelor politice din Republica Moldova: aspecte politico-sociale. In: Academia de Ştiinţe a Moldovei. Revista de filosofie, sociologie şi ştiinţe politice, 162 (2), pp. 55-65. 
- BÜSCHER, K. (2004) Das politische System Moldovas. In: ISMAYR, W. (ed.) Die politischen Systeme Osteuropas. $2^{\text {nd }}$ ed. Opladen: Leske + Budrich, pp. 515-552.

- BÜSCHER, K./ AVRAM, A. (2012) Parteien. In: BOCHMANN, K. et al. (eds.) Die Republik Moldau. Republica Moldova. Ein Handbuch. Leipzig: Leipziger Universitätsverlag, pp. 292-308.

- DELlenbrant, J. A. (1993) Parties and Party Systems in Eastern Europe. In: WHITE, S./ BATT, J./ LEWIS, P.G. (eds.) Developments in East European Politics. London: Pallgrave, pp. 147-162.

- GOŞU, A. (2016) Interview. In: cursdeguvernare.ro [online magazine] $27^{\text {th }}$ April. Available from: http://cursdeguvernare.ro/interviu-armand-gosu-la-chisinau-se-da-olupta-pe-viata-si-pe-moarte-pro-rusul-dodon-are-cele-mai-mari-sanse-sa-ajungapresedinte-in-moldova-ar-trebui-reconstruit-totul-de-la-zero-cu-oameni-noi.html [Accessed 09/09/17].

- IBENSKAS, R./ SIKK, A. (2016) Mergers and splits: How party systems have changed in Central and Eastern Europe since 1990. [Weblog] European Politics and Policy. $3^{\text {rd }}$ October. Available from: http://blogs.lse.ac.uk/europpblog/2016/10/03/party-systemschange-central-eastern-europe-since-1990/ [Accessed 07/09/17].

- INSTITUTUl DE POLITICI PUBLICE (2014) Barometrul Opiniei Publice. Republica Moldova. Octombrie-Noiembrie 2014. Chişinău: IPP. Available from: http://ipp.md/old/public/files/Barometru/Brosura_BOP_11.2015_prima_parte_final.pdf [Accessed 08/09/17].

- INSTITUTUL DE POLITICI PUBLICE (2015a) Barometrul de Opinie Publică. Republica Moldova. Aprilie 2015. Chişinău: IPP. Available from: http://ipp.md/old/public/files/Barometru/BOP_04.2015_prima_parte_finale.pdf [Accessed 08/09/17].

- INSTITUTUl DE POLITICI PUBLICE (2015b) Barometrul Opiniei Publice. Republica Moldova. Noiembrie 2015. Chişinău: IPP. Available from: http://ipp.md/old/public/files/Barometru/Brosura_BOP_11.2015_prima_parte_final.pdf [Accessed 08/09/17].

- INSTITUTUl DE POLITICI PUBLICE (2016a) Barometrul de Opinie Publică. Republica Moldova. Aprilie 2016. Chişinău: IPP. Available from: 
http://ipp.md/old/public/files/Barometru/BOP_04.2016_prima_parte_finale-r.pdf [Accessed 08/09/17].

- INSTITUTUl DE POLITICI PUBLICE (2016b) Barometrul de Opinie Publică. Republica Moldova. Octombrie 2016. Chişinău: IPP. Available from: http://ipp.md/old/public/files/Barometru/BOP_10.2016.pdf [Accessed 08/09/17].

- INSTITUTUL DE POLITICI PUBLICE (2017) Barometrul Opiniei Publice. Republica Moldova. Aprilie 2017. Chişinău: IPP. Available from: http://ipp.md/old/public/files/Barometru/Magenta_BOP_final_v3_27_apr.pptx [Accessed 08/09/17].

- IRMER, S.-J. (2015) Knapper Sieg pro-europäischer Parteien. Kommunalwahlen in der Republik Moldau. [Weblog] KAS-Länderberichte. $16^{\text {th }}$ June. Available from: http://www.kas.de/wf/doc/kas 41723-544-1-30.pdf?150616165828 [Accessed 07/09/17].

- IRMER, S.-J./ AVRAM, A. (2015a) Pro-europäische Parolen und stagnierende Reformen. Neue Regierung in der Republik Moldau. [Weblog] KAS-Länderberichte. $31^{\text {st }}$ July. Available from: http://www.kas.de/wf/doc/kas_42162-544-1-30.pdf?150731150153 [Accessed 08/09/17].

- IRMER, S.-J./ AVRAM, A. (2015b) Herbst der Proteste. [Weblog] KAS-Länderberichte. $17^{\text {th }}$ September. Available from: http://www.kas.de/wf/doc/kas_42552-544-130.pdf?150917115913 [Accessed 08/09/17].

- KESTElOOT, S./ DE VRIES, P./ DE LANDTSHEER, C. (2008) Branding the Mayor: Introducing Political Consumerism in Belgian Municipal Elections. In: LILLEKER, D./ SCULLION, R. (eds.) Voters or Consumers: Imagining the contemporary electorate. Newcastle: Cambridge Scholars Publishing, pp. 73-96.

- NELSON, S. et al. (2010) Moldova Democracy and Governance Assessment. Final Report. Bethesda: Democracy International. Available from: http://democracyinternational.com/media/Moldova\%20Democracy\%20and\%20Governan ce\%20Assessment.pdf [Accessed 07/09/17].

- NEMERENCO, D. (2008) Politics of Transition: A Waste of Votes?. Unpublished thesis (AB), Harvard College. Available from: http://www.ipp.md/old/public/files/Publicatii/2008/Thesis_Final.doc[Accessed 07/09/17]. 
- PARTIDUl ACŢIUNE ŞI SOlIDARITATE (2016) Statutul Partidului Politic "Partidul Acţiune şi Solidaritate” (PAS), Chişinău. Available from: http://www.edemocracy.md/files/parties/pas-statute-2016-ro.pdf [Accessed 08/09/17].

- PISICA, G. (2013) Reflecţii privind sistemul pluripartidist din Republica Moldova. Tyragetia, vol VII [XXII], no. 2, pp. 311-315.

- PROTSYK, O./ BUCĂTARU, I./ VOLENTIR, A. (2008) Competiţia partidelor în Moldova. Ideologie, organizare internă şi abordarea conflictelor etno-teritoriale. Chişinău: CEP USM.

- SIEG, H. M. (2017) Wahlrechtsänderung in der Republik Moldau gegen VenedigKommission und EU verabschiedet. [Weblog] KAS-Länderberichte. 24 ${ }^{\text {th }}$ July. Available from: http://www.kas.de/wf/doc/kas_49655-1522-1-30.pdf?170724123746 [Accessed 07/09/17].

- WEBSTER, J. (2008) Parliamentary majorities and national minorities: Moldova's accommodation of the Gagauz. Unpublished thesis (DPhil), University of Oxford. 